\title{
Media-Tech Advancements-Based Mass Communication and SOEs \& Public Institutions' Innovations for Party-Building Publicity and Education in the All-Media Era
}

\author{
Jing Sun ${ }^{1}$ Youbin Chen ${ }^{2 *}$ Jinsheng Sun $^{3}$ Yuke Dan ${ }^{4}$ \\ ${ }^{1}$ General Management Department, Aerospace CH UAV Co., Ltd. Beijing, China \\ ${ }^{2}$ School of Foreign Languages, Sichuan University of Science \& Engineering, Zigong, China \\ ${ }^{3}$ School of Marxism, Yanshan University, Qinhuangdao, China \\ ${ }^{4}$ Law School, Lanzhou University, Lanzhou, China \\ *Corresponding author. Email: robinchen@vip.qq.com
}

\begin{abstract}
This is an all-media era, for various new media including social media like Weibo and YouTube feature text, graphics, audio and video supported by digital technology, accommodate fragmentation and interactive communication and encourage online/offline social circles integration. This paper first surveys technological advancements and analyzes their impact on media and mass communication in history, then observes various challenges for SOEs and public institutions' party-building publicity and education, and finally recommends that we should advance with times to break through stereotyped modes and work out innovative strategies.
\end{abstract}

Keywords: media-tech advancement; mass communication; party-building publicity \& education; innovation.

\section{INTRODUCTION}

Party-building publicity has been a top priority for cultural construction and ideological \& political work, playing a big role in ideological education, enhancing corporate solidarity, and guiding our future development. For a long time, we have followed a set of our own methods to promote party solidarity to help our progressive development. In recent years, however, as information technology is advancing quickly, new media are developing rapidly and have brought about great changes in mass communication. People now prefer to have new ways of receiving information and have developed new reading habits.

In this context, our corporate party-building publicity requires that we take active measures to break through those stereotyped modes and make innovative strategies for party building publicity. Thus, we should take a close look at new media and mass communication, identify and analyze new challenges, break through conventional modes, and find new approaches to enhancing party-building publicity, so as to help us to adapt to various new changes in mass communication, and ensure our due role in this new era.

\section{MEDIA-TECH ADVANCEMENTS AND MASS COMMUNICATION}

\subsection{Technological Advancements and Mass Communication}

Media communication, from the agricultural society, to the industrial society, and to the modern information society, has been evolving, compensating and developing endlessly, along with the everlasting development and change of technological means [1]. This has brought about unceasing social cultural evolution and changes. Media communication used to be a monopoly of the elite, and has entered into the mass epoch for long. Now the era of individuality has emerged and it is still going deeper. Before the Han Dynasty, exchange and communication in text had been 
strictly confined to a very small circle of powerful officials and influential figures. Thanks to inventions like paper making in Han, woodblock printing in Tang and movable-type printing in Song, the costs for media have been decreasing, so ideas, knowledge, literature and culture have been spreading in a quite large scope, and the intellectual community has gradually come into being.

In modern times, as newspaper emerged gradually, and especially after the New Culture Movement in China, vernacular Chinese has been valued and promoted, and mass communication has become a reality, involving all walks of life and reaching each corner of the world. Nowadays, presswork, radio and $\mathrm{TV}$, and particularly various popular online media and platforms formed by information technology, have been popularized, making the two-way interactive mass communication in the true sense a reality.

\subsection{Emerging All-Media Era}

In this Internet era for mankind, digital media centering on the Internet have incorporated various symbols, codes, signals and physical carriers as media, representing comprehensive remedy for and transcendence over books and periodicals, newspaper, radio and TV [2]. As Facebook was launched in 2004, QQ space was provided in 2005, and other social network sites have been getting fashionable around the globe, the Web 2.0 mode that gives priority to user interaction has emerged, making users content viewers and producers. The reality that users are producing content has become a distinctive feature of social network-based social media. Recently, smart phones and other mobile terminals and APPs have been widely popularized, and the era of mobile Internet has emerged. On the US's Twitter and China's Weibo and WeChat, users are building their own interpersonal network, making media and socialization an integrated whole [3]. Nowadays, video platforms like YouTube, Bilibili and Douyin are very fashionable. In 2020, WeChat and Weibo also launched their short video features. To date, social media as platforms integrating sound, text, graphics and video on social media are ushering into the all-media era.

\subsection{SNS: Fragmentation and Interactiveness}

Social media are of a technical nature, as a great accomplishment integrating digital technology, telecommunication, Internet and interactive communication. Their high capacity, time-space transcendence, hypertext, hypermedia, and quick-search properties have brought about five changes involving unifying openness \& stealthiness, equality \& extensibility, plurality \& quantization, autonomy \& interactivity, and storage capacity \& duplicability. Individuals now serve as message producers and receivers. The logic "Content is king" facilitates fragmentation and interactive communication, and online/offline social circles are coming together, so they represent as media multipliers, information transmission channels, and message filtering channels, with the help of mobile intelligent terminals to extend the functions of our sense organs, with text and graphics to enhance our vision, radio broadcasting to extend our hearing, and video to facilitate both and even enhance our sense of touching [4].

At present, short video has accommodated mobile Internet-based social media's fragmentation and interactive communication, and become an important form of socialized We-Media production. It is now changing the ecological pattern of public opinion online. Short video is not just an important channel of whistleblowing, pubic supervision, news coverage, hot issue debate, and public sentiment dissemination online, but also plays a paramount role in promoting diversified communication and cultural publicity [5].

Fragmentation and interactive communication feed on social media's breakthrough of spatio-temporal limitation, but undoubtedly fragmentation has its own deadly drawback, for it goes against systematicity. As a result, deliberate misinterpretation out of context and even rumors and pseudoscience are propagating their belief on a large scale [6] Thus, it is necessary for us to make use of fragments as starting points of our interest, and then extend the space, time and depth for our content, to ensure systematic information communication.

Based on the above review, we sum up technological means, media, and mass communication (disseminators vs. audience) in history as in the table below:

Table 1. Tech-advancements, media and mass communication in history

\begin{tabular}{|l|l|l|l|l|}
\hline $\begin{array}{l}\text { Period/Tech- } \\
\text { means } \\
\begin{array}{l}\text { Givers } \\
\text { Receivers }\end{array}\end{array}$ & $\begin{array}{l}\text { Pre-Han: } \\
\text { Bamboo }\end{array}$ & $\begin{array}{l}\text { Han/Sui/Ta } \\
\text { ng/Song- } \\
\text { now: } \\
\text { Paper \& } \\
\text { printing }\end{array}$ & $\begin{array}{l}\text { 1919-now: } \\
\text { Radio/TV }\end{array}$ & $\begin{array}{l}\text { 1991-now: } \\
\text { Internet/All } \\
\text {-media }\end{array}$ \\
\hline $\begin{array}{l}\text { Elite } \rightarrow \\
\text { Elite }\end{array}$ & $\begin{array}{l}\text { Visual: } \\
1: 10,000+{ }^{a}\end{array}$ & & & \\
\hline $\begin{array}{l}\text { Author } \rightarrow \\
\text { Intellectuals }\end{array}$ & & $\begin{array}{l}\text { Visual: } \\
1: 1,000- \\
8,000^{a}\end{array}$ & & \\
\hline $\begin{array}{l}\text { Author } \rightarrow \\
\text { Mass }\end{array}$ & & & $\begin{array}{l}\text { Visual/Audi } \\
\text { o/Electro- } \\
\text { magnet: 1: } \\
100-900^{\mathrm{a}}\end{array}$ & \\
\hline $\begin{array}{l}\text { Author/mass } \rightarrow \\
\text { Author/mass }\end{array}$ & & & & $\begin{array}{l}\text { Visual/Aud } \\
\text { io/Electro- } \\
\text { magnet/Dig } \\
\text { ital: } 1: \mathrm{n}\end{array}$ \\
\hline
\end{tabular}

a. Based on statistics of China's third census in 1987 


\section{OLD STEREOTYPED MODES TO PROMOTE PARTY CONSOLIDATION}

To make innovations, we have to break through those stereotyped modes. We SOEs' and public institutions' party-building publicity teams first have to break up those fixed conventions that fail to accommodate new developments or meet various challenges in this new media era.

\subsection{Conventional Thinking Limitations}

Some party-building workers in SOEs and public institutions are still sticking to conventional thinking modes in their publicity work, and in the face of new media, they have two typical thinking modes: First, repulsion. They think that party-building publicity must always stay serious, and the correct approaches to this end include periodicals and newspapers, display boards and posters, and offline panel discussion, and they are inimical to new media's flexible role in party-building publicity, not willing to change their manner or attitude to better interact with their audience. Second, contempt. They do not have sufficient recognition of the helper role of new media, so they unwilling to make enough effort to seek useful means to use new media to mobilize their audience, and enlarge their publicity effect. As a result, some party-building publicity efforts have been made as a mere formality in the name of new media, and not ended up with favorable results. Thanks to these cognitive limitations in thinking, some SOES and public institutions are still using those "outdated" patterns and methods to do party-building publicity, as is not that popular with their audience, especially new CPC members.

\subsection{Old Content Production Modes}

The new media era is being visualized. In the context of fragmentation and light reading for message presentation to accommodate the audience, a fundamental starting point for visualization is to present information in a concrete manner, and systematize fragmentary messages, to enhance their readability, friendliness and legibility to serve our audience better [7]. At present, some SOEs and public institutions are still confined to long texts when it comes to partybuilding publicity. The style of writing is serious, monotonous and lack of delights. This is not in line with our reading scenarios in the context of new media; let alone allowing our audience an opportunity to really feel for and remember those ideas concerning party building whole-heartedly.

\subsection{One-Way Dissemination Mode}

The new media era is being visualized. In the context of fragmentation and light reading for message presentation to accommodate the audience, a fundamental starting point for visualization is to represent information in a concrete manner, and systematize fragmentary messages, to enhance their readability, friendliness and legibility to serve our audience better [8]. At present, some SOEs and public institutions are still confined to long texts when it comes to party-building publicity. The style of writing is serious, monotonous and lack of delights. This is not in line with our reading scenarios in the context of new media; let alone allowing our audience an opportunity to really feel for and remember those ideas concerning party building whole-heartedly.

\subsection{Old Content Reception Mode}

The new media era is interactive. Interaction means that the audience can have full participation in the process, with higher autonomy. If our mode of discourse and mechanism of dissemination evolve to accommodate the demand of the audience, this dissemination will become effective communication; otherwise, it will be inefficient or ineffective [9]. This requires that we make an effort to enhance the audience's sense of experience and participation, making good use of various modes to communicate effectively with our audience. Some SOEs' and public institutions' party-building publicity departments always disregard the feeling of our audience.

Without a workable mechanism for interaction and feedback, they only use some outmoded dissemination forms to bring about one-way information transmission. The audience cannot find any enjoyment, and may easily get lost in overloaded messages. This way, our publicity teams cannot play a guiding role in promoting ideology and politics.

\section{INNOVATIVE STRATEGIES FOR PARTY-BUILDING PUBLICITY AND EDUCATION}

Having surveyed those stereotyped modes, we consider the background of new media, and find that we SOEs and public institutions should make innovations at various levels, to drive our party-building publicity and education forward.

\subsection{An All-Media Thinking Mode}

To make innovations unnecessarily means to get rid of all old methods, but to clearly understand the current scenario of mass communication where conventional 
media and new media are competing against each other. We need a holistic perspective and all-media thinking, to advance with times in the context of the current communication environment. The all-media thinking is not just about multiple channels, but how to have pointto-point transmission to ensure clear vertical communication, and the audience can choose the message based on their individual interest and demand [10].

To build up all-media thinking, we should center on our audience and explore for party-building publicity approaches and guide our party-building publicity behaviors. We should not rely on those stiff preaching words, but use more pleasant and delightful discourse expressions and information presentation approaches, to help our audience to feel for party-building publicity. Meanwhile, we need to have sufficient knowledge and understanding of different media types, break through our convention-based knowledge, mindset and patterns, to include our efforts concerning corporate partybuilding publicity into the great scenario of all-media communication. We can make use of some resources from Xuexi Qiangguo app, and produce and release some videos on Weibo and WeChat, so that our publicity text, pictures and clips could be integrated and promoted on these platforms.

We can create some works during some fragments of free time, making use of fragmented text space, integrating text, pictures, music, video and other symbols into one, to enhance the perception of our audience including sense of substitution, sense of participation and sense of immersion, drawing us close to our audience, to their ears, their eyes and their souls.

\subsection{A Multi-Channel Publicity Mechanism}

Our party-building publicity efforts are not one-off input-output project, but need to involve an all-rounded diversified publicity framework, where the voice of our party can be delivered to our audience through various channels. In 2019, general secretary Xi Jinping stressed at the 12th Collective Learning Session of the 19th Political Bureau of the Central Committee of the Communist Party of China, "We shall make more efforts in developing innovative communication approaches, making use of various new media platforms like websites, Weibo, WeChat, electronic newspaper reading screens, mobile phone newspaper, and IPTV to actively develop various interactive, service-like and experiential news and information push services, so that the voice of our party could come out on various user terminals, and take hold of the new public opinion field"[11]. The speech was delivered for the media industry, but is indeed pertinent to party-building publicity around SOEs and public institutions.
Nowadays, it is almost impossible for us to employ one single dissemination approach to meet the demand for party-building publicity, so we need to choose more flexible publicity approaches, so that we can do better in promoting our mainstream ideology, and ensure our publicity is convincing and persuasive [12]. To ensure better party-building publicity, we should make use of various communication channels, and support our publicity via these channels with due operation mechanism and staffing, to ensure our publicity work go smoothly. For example, competent personnel should be designated for our official accounts on Weibo and WeChat. They should be linguistically competent and experienced in social media operation, and also be willing to serve our audience and ready to address some emergency. Some relevant incentives can be provided to attract and retain followers.

\subsection{An All-People-Involvement Mode}

In this new media era, our audience could be quite powerful, helping our voice to go viral. In the context of social media, message dissemination is based on the cultural demand and personality of our audience, and we have to respect their subjectivity [13. SOEs and public institutions should develop an open mode of thinking for party-building publicity and education, realizing the power of our audience, and allowing more of them to get involved. They can either forward our text, pictures and videos, or create some derivative works, or add some comments.

To this end, we can mobilize our human resources, like some party members. We have some advantages in this regard, for we have a lot of competent talents, and we can encourage their participation. We can also create some interactive approaches to accommodating our audience timely, so that they can be impressed, and even get involved in promoting our publicity at their free will. This way, our publicity may go viral, and becomequite influential.

\subsection{An Emergency Alert and Response System}

Given that the public opinion in the context of web 2.0 and social media in this new era is quite complicated, some emergency may occur. Social media due to fragmentation, interaction and multiplication help our publicity to go far, our errors may be multiplied, and misinterpretation out of context, rumors and pseudoscience may occur and go viral. We should always bear this in mind, minimize our mistakes and stay on alert. We may have contingency plans for some important events, and consider how to develop a kind of emergency alert and response system. In case some emergency does occur, we can stay calm, and address it in an orderly manner, to avoid more adverse 
repercussions. We shall always remember the Internet is no place outside of judicial reach. On one hand, we should work in an ethical and lawful manner; on the other hand, we can go to our legal institution for a way out when necessary. In short, we should always maintain our alert, quick wit and calmness, ethical and legal awareness as successful communicators in our efforts to promote party-building publicity.

\section{CONCLUSION}

To sum up, medium means and mass communication have been evolving with technological innovations in history. In this Web 2.0-based all-media era now, text, graphics, audio and video are integrated on SNS and other new media to accommodate fragmentation, interactive communication and online/offline integration. Various new challenges for party-building publicity, like complex and diversified media patterns, disseminator-audience relationship changes, decentralized dissemination modes and more complicated public opinion environment have risen up, so we should advance with times, break through some stereotypes modes and work out some innovative strategies, like building up our all-media thinking, establishing a diversified publicity mechanism and developing an all-people-involvement mode, so that various forces can be mobilized to ensure better partybuilding and ideological publicity and education.

\section{ACKNOWLEDGMENTS}

The authors acknowledge the funding of Research Center for International Communication of Sichuan Liquor Culture (CJCB2020-04) and Sichuan Federation of Social Sciences Associations (21BS031).

\section{REFERENCES}

[1] P. Levinson, "Digital mcluhan - a guide to the information millennium" (M), London: Routledge, 1999.

[2] T.Y. Yang, "Media evolution theory - starting from Paul Levinson, Southeast Communication" (J), 2009 (03),pp. 28-29.

[3] T. Tian \& ZJ. Zhang, "The status quo, development and trends of social media in China", Editorial Friends" (J), 2017 (1),pp.20-25.

[4] J.M. Long. "Gradual evolution and impact: dynamic features and new functions of interpersonal communication in the new media era", Journal of the West (J), 2017(10)pp. 47$49+72$.
[5] P.F. Liu, "Multiple dimensional approaches to progressive research on public opinion in China", China Newspaper Industry (J), 2021 (11),pp. 42-43.

[6] P. Yang \& TM. Shi, "Fact vs. fiction game: scientific dissemination mechanism on weibo-a case study of weibo as a rumor grinder", Journalism Research(J), 2011(04),pp. 145-150.

[7] Q. Lu, "Gate-keeper theory evolution and development in the context of new media" [J]. New Media Research, 2018,4(20),pp.15-16.

[8] C.B. Wang \& H. Teng, "Towards news visualization in the new media era" $[\mathrm{J}]$. Journal of News Research, 2014, (3),pp. 3-5.

[9] H.F. Wang. "Towards innovative news publicity in soes from the perspective of audience" [J], Journal of News Research, 2017,8(21),pp. 170-171.

[10] H.B. Zhang \& K. Wang. "Reconstruction, rebuilding and reshaping - on media convergence with all-media thinking" $[\mathrm{J}]$. Explore Science, 2019(4),pp. 285.

[11] L.D. Chen, "Xi Jinping's remarks on 'building all media"” [J]. Journalism Lover, 2019(4),pp. 4-6.

[12] W.L. Zhang, "Towards enhancing party-building publicity in SOEs with new media" $[\mathrm{J}]$, Youth Times, 2018(20), pp. 53-54.

[13] L. Yue. "New-media dissemination and audience participation culture development" $[\mathrm{J}]$. Press Outpost, 2021(2), pp. 25-26. 